\title{
Current Halal Market and Corporate Social Responsibility Practice: An overview
}

\author{
Zaki Ahmad ${ }^{1}$, Md Mahfujur Rahman²*, Mohamad Helmi Bin Hidthiir ${ }^{3}$
}

${ }^{1,3}$ School of Economics, Finance and Banking, Universiti Utara Malaysia, 06010, Sintok, Kedah, Malaysia

${ }^{2}$ Islamic Business School, Universiti Utara Malaysia, 06010, Sintok, Kedah, Malaysia

DOI: $10.36347 /$ sjebm.2020.v07i08.007

| Received: 04.08.2020 | Accepted: 12.08.2020 | Published: 26.08.2020

*Corresponding author: Md Mahfujur Rahman

\section{Abstract}

Review Article

The current Halal industry is growing rapidly with increase number of both Muslim and non-Muslim consumers. The recent globalization is one of the important factors along with the technological advancement for consumers' preference of the Halal food products. Although there is a huge demand of the Halal products and services based on Halal certification and assurance, but the current Halal industry has overlooked the importance of Corporate Social Responsibility (CSR) practice. However, for Halal industry, CSR should be a part of strategic planning for orientation of the business to the society. It should be based on the Islamic business ethics that give emphasis to the benefit of the humanity and environment to follow the order of Allah SWT. Halal industries are accountable for their actions and behaviors with better transparency of their business activities and operations. Therefore, this paper will give primarily an orientation of CSR along with the Islamic perspective. Furthermore, it will explore the current CSR understanding of the consumers of the Halal products with giving importance to the society with good governance and transparency practice. Thus, it revealed the Halal CSR information, consumer's perspective of Halal CSR and perceived CSR activities in Halal industry. Furthermore, the study will also provide suggestions about the contribution of CSR in Halal industrial sustainability by incorporating the societal and monetary roles of the business.

Keywords: CSR, Halal industry, Halal food consumer, Halal CSR information.

Copyright @ 2020: This is an open-access article distributed under the terms of the Creative Commons Attribution license which permits unrestricted use, distribution, and reproduction in any medium for non-commercial use (NonCommercial, or CC-BY-NC) provided the original author and source are credited.

\section{INTRODUCTION}

In referring to Halal, the business openings are not just restricted to the food and non-food division, but it also covers the official segment, for instance, finance and banking, insurance, educational trainings, research work, certification, consultancy, co-ordinations, medicinal services and tour and travel services. The enterprises which related to the Halal are moving forward to the lucrative industry and in national and international level there is a vast opportunity for halal trade. In the present time people are heading towards the Halal food and other Islamic consumer products day by day. Yaakob [1] and $\mathrm{Li} \mathrm{Za} \mathrm{[2]} \mathrm{mentioned} \mathrm{that} \mathrm{the}$ number of Muslims are 1.8 billion universally, consisting around 20 percent of the total population of the world. The given table below shows the breakdown of Muslims population worldwide. From the industry point of view everybody gets a great business opportunity through the Halal idea, without an exception of the religion. It is advertised as another growth segment considering the immense potential right now. The rising fortune of Muslims worldwide and the increasing awareness on Halal have made high demand for products which is Halal.

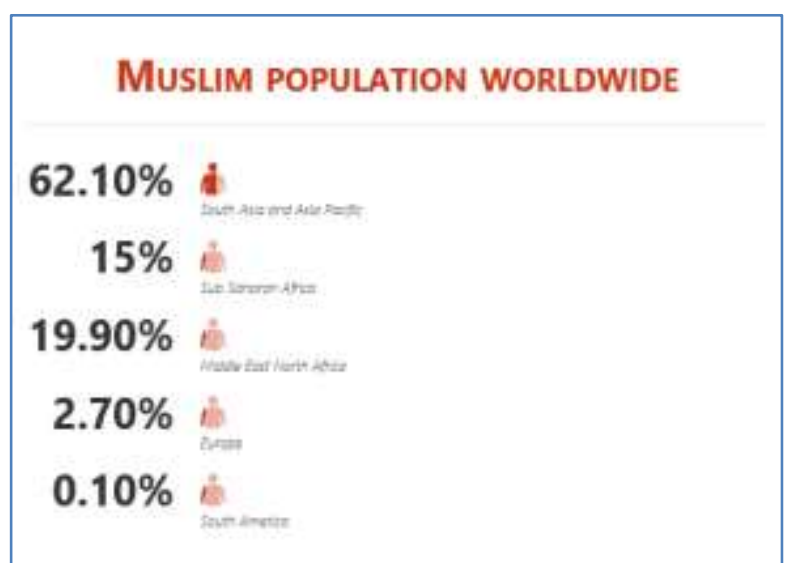

Fig-1: Muslim population worldwide (Adapted from: The global Halal industry: an overview [3]

The evaluation of worth for the whole Halal industry is USD \$2.3tril (RM7.4tril) which incorporates food and beverage, pharmaceuticals, cosmetic items and personal care, excluding banking. This is notable that 
the food market worldwide is being keen for the "Halalan Thoyyiban" idea as another drive for advertising food products. According to Yaakob [1] it is necessary for the industry to understand and appreciate the spiritual and scientific basis of Halal requirement to tap this lucrative market. Every Halal item ought to be synonymous with the best in the market, as far as quality and incentive for cash, with the special reward, that the items are totally worthy for Muslims because of the Halal certification. In this context, it is necessary to guarantee that there is thorough and exhaustive methodology adopted, for the Halal certification, in order to ensure authenticity and the trustworthiness of the certificates [4].

Corporate social responsibility (CSR) is described as "organizations' consideration and response to the problem which goes far from the legal need, along with practical and economic of the firm" [5]. While Carroll [6] describes CSR as "social duty of business encompasses the lawful, financial, moral and discretionary wants that society has of relationship at a given point of time". However, Suhana [7] defined CSR as an idea whereby firms might be considered socially and morally responsible by a variety of partners which incorporate clients, representatives, governments, networks, NGOs, financial specialists, providers, associations and regulators. Furthermore, the definition of CSR under the Sustainable Development is "the procedure with obligation by business to behave ethically and enhance improvement related to monetary while enlightening the individual fulfilment of the workforce and their families just as the close by system and society at large" [8].

According to the concept of CSR, in the current era there are some responsibilities which organizations are liable to do for the society, that stretch out past their promises to the financial specialists or the stockholders of the firm [9]. Generally, the elements of CSR consolidate work force, condition security and worker support, equivalent chances, network support, corporate philanthropy, items, representation of minorities, revelation of social data and representation of ladies [10]. To strengthen trust with the general public and acting competently towards purchasers, providing firms an advantage in drawing in clients and representatives, laborers and others in the community can assist organizations with improving their level and value. Greater investors' consciousness of CSR; direct partners' pressures; and an extended feeling of buyer's social duty are a kind of the important drivers that significantly influence growing business center around CSR [11].

\section{Corporate Social Responsibility and Islam}

CSR has become a motivation in numerous nations for their enterprises. The European Commission for instance, made a dedication in European Union to advance CSR which accepts that CSR can build clients' trust and make long term relationship. The characteristic of CSR according to European Commission [12] is "it is an initiative through which industries coordinate ecological and social worries in their trading activities and in their cooperation with their partners on a willful premise."

The European Commission encourages the businesses in Europe to do their best in providing their products and services that add value to the society [12]. Mc William and Siegel [13] described CSR as: "tools which appears to facilitate many social good, along with keenness of the company and the thing which is compulsory by law". Carrol [14] in his paper deliberated the CSR pyramid which consists of four responsibilities. i.e. Economics, Legal, Ethical and Philanthropic responsibilities. The economic responsibility of the CSR stresses on the important of the business to consistently making high profit and competitive in the market. The legal responsibility stresses on how a business should ensure that they perform in a manner that consistent with legal requirements or at least meet minimal legal regulations. The ethical responsibility focuses on how a business conducted ethically as expected by the society whereby the philanthropic responsibility shows how important a business voluntarily involves in charity, fine arts, education and activities that can improve the standard of life of the members of the community. The following figure illustrates the CSR pyramid suggested by Carrol [14].

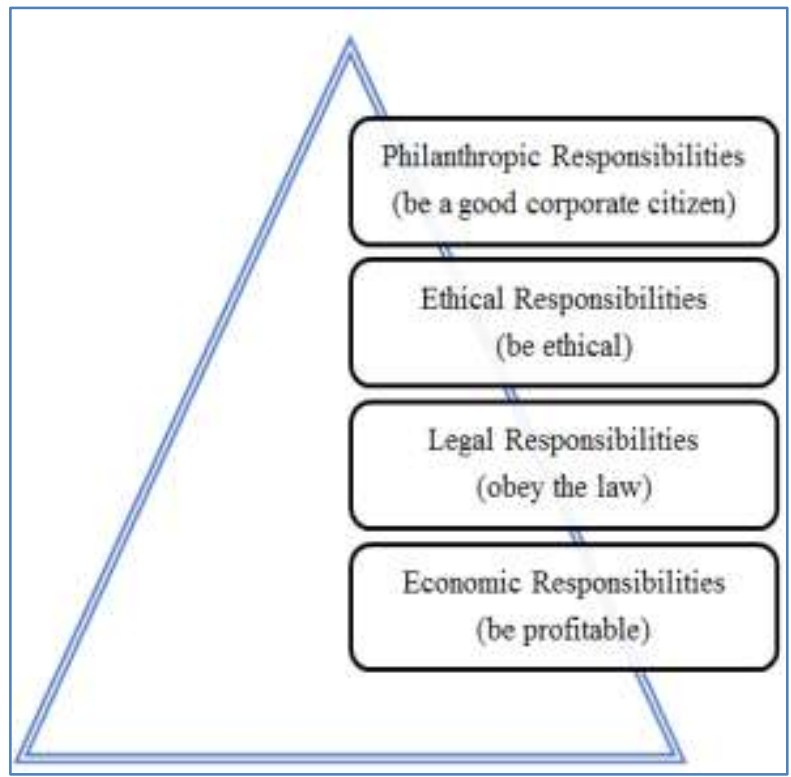

Fig-2: Corporate Social Responsibility Pyramid. ((Adapted from: The Pyramid of Corporate Social Responsibility: Toward the Moral Management of Organizational Stakeholders [14].

CSR from the Islamic perspective or known as Islamic CSR (iCSR) is derived according to the need of Maslaha (public good) suggesting at sustainable development [15]. 
Dusuki and Abdullah [16] explain the CSR according to different level of necessity fulfillment. They describe the essentials (daruriat) as the major fundamental responsibility along with other two complementary (hajiyat) and embellishments (tahsiniath) for applying the CSR programs [16]. Thus, from the Islamic point of view, business execution is assessing based on how well the assets are managed to progress the community. The idea of ummah exhibits that community has a privilege and stake in whatever a Muslim possesses [17]. The Islamic Business
Organization (IBOs) is socially accountable to the people of the community along with the environment. The community comprise of the people like stockholders, bosses, clients, dealers, government, public and debtors. The figure 2 shows the CSR Model from Islam, where it has a relation to the achievement of human life. The model highlights that the main objective of humankind is to achieve al-falah i.e. an eternal victory in both of the world with the blessings of God.

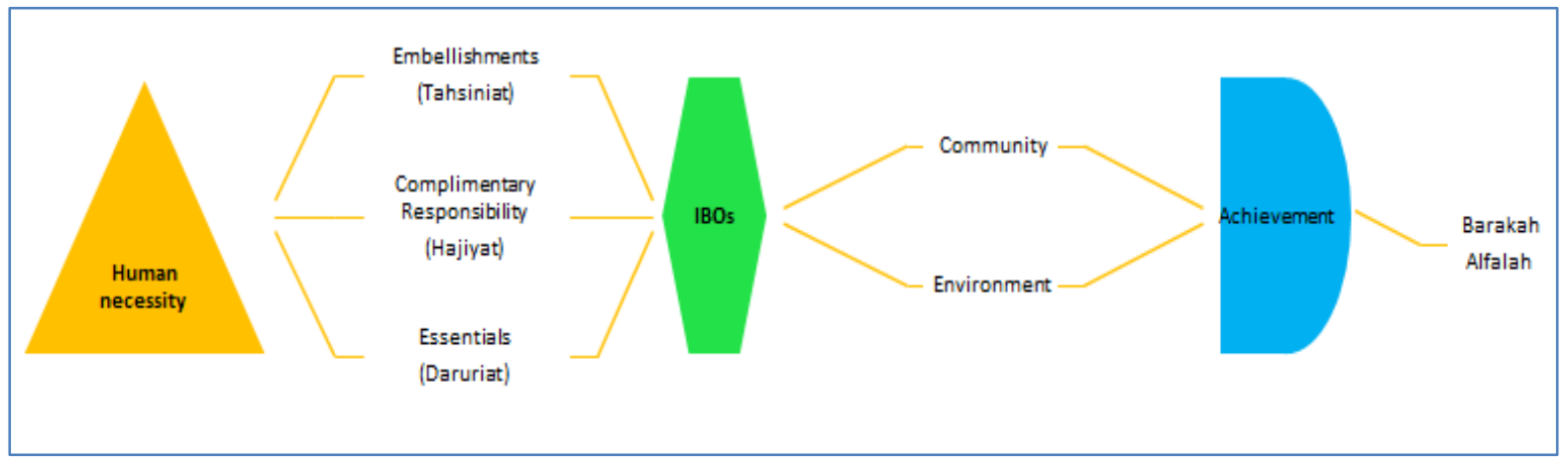

Fig-3: Corporate Social Responsibility from Islamic Perspective.

\section{Current Halal Industry}

The Halal industry is growing rapidly at global level. Not just Muslims give and use Halal items and services in the current era. In fact, it has become a productive business as it satisfies the requirements of Muslims, however it additionally catches the interest of non-Muslim buyers. Among the elements for tolerating Halal items and services beside religiosity is globalization.

Consumers grasp new culture and preference through the globalization and technology advancement. With increasing interest for Halal items and services concentrating on Halal certification, the Halal business has disregarded the significance of CSR which is significant as per Islamic teachings.
As indicated by the Islamic economy report 2017/18, the estimation of the Halal market globally was valued around $\$ 2.06$ billion out of 2016 and predicted to be $\$ 3.08$ billion by the year 2022 [18]. Currently, the opportunity of Halal has moved far from the food-focused to different parts together with design, travel, beauty care products, pharmaceuticals, and media. These are the reasons because of which the industry has become the quickest developing consumer segments on the planet. The upcoming figure demonstrates the market measurement of the Halal economy sectors (Islamic finance is not included in this) and the predicted measurement by the year 2022 .

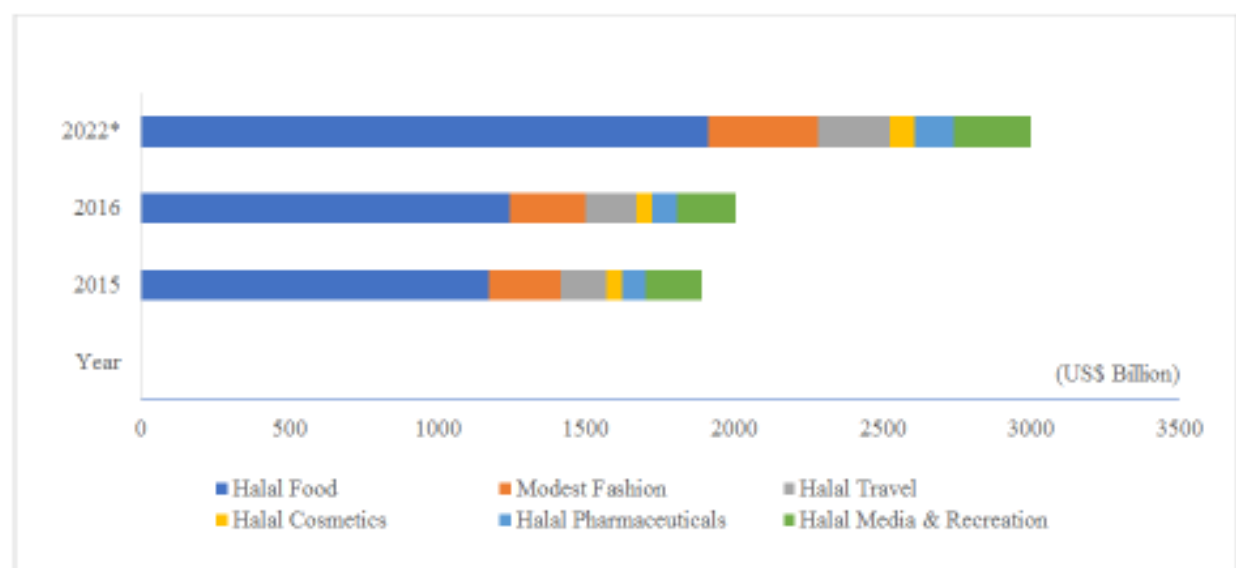

Fig-4: The expected market size of global Halal economy; Sources: Thomson Reuters' global Islamic economy report 2016/17 and 2017/2018 [18]. 
The idea of Halal and Haram is different from the ethical concept of right and wrong [19] where ethics is derived from mankind and it is subjective according to factors including time, location and culture. Halal and Haram is a clear-cut regulation that is guided by Shariah and by performing Haram activities, one may be punished by God. It is enlightened in the Hadith.

"Halal (lawful) and Haram are explicit; in the between of these both there are things which are ambiguous and that are suspected (Shubha). Many individuals may not be aware of that whether those things are permitted or not. Whoever leaves those things, he is guiltless towards his faith and his conscience. In this manner, he is, safe. Any individual who engages in any of these presumed items, he may commit the illicit and the forbiddance. This matter is like the person who wants to look after his creatures alongside a confined territory, he may step into it. Indeed, for each property-owner there is a confined region. Undoubtedly, the limitations of Allah are the unlawful (Haram)" [20].

The above Hadith shows that the importance of Halal and Haram is to be embedded in our daily activities including business.

However, in Malaysia Halal industry is a national agenda. Malaysia has become the leading country in Halal certification and aims at becoming the international Halal hub in 2020. The Halal market size in Malaysia is predicted to be USD1.9 billion with a huge contribution of $90 \%$ by the food industry [21]. The Halal agenda in Malaysia is moving toward a comprehensive Halal ecosystem initiated by the government; hence the development of eleven strategic thrusts of the global Halal hub. The Halal ecosystem definition includes new Muslim consumers, global Halal standard, comprehensive Halal ecosystem, Halal economy, Halal integrity and human capital [21]. Although CSR is not specifically mentioned in the dynamics of developing the thrusts, there is a dire need to address the issue of CSR in the Halal industry as CSR articulates the socioeconomic justice in the Islamic moral economy.

\section{The Potentiality of Halal Food Market}

The sizeable and developing Muslim population overall manages the improvement of the Shariah compliant food industry, notwithstanding the developing financial advancement in the countries where Muslim are in majority and the potential of the growth for the Shariah compliant industry in the countries where non-Muslim are in majority e.g., China and India. There are around 25 percent Muslims globally out of the total population of the world, and majority of them are living in countries like, Indonesia, Malaysia, Iran, Saudi Arabia, Egypt and Morocco. According to the information which is issued by the Pew Research Center [22], in the Asia-Pacific area around 62 percent Muslims are populated, which along these lines comprises an immense market potential for halal food.

The halal market is never again bound distinctly to Muslim nations and it is currently spreading to the countries where non-Muslims are populated. In the past, the utilization of Shariah compliant food was engaged in the countries where Muslims are in majority. This is a notable thing that now the non-Muslims countries who has honored the Shariah compliant food with another standard to protect, fresh and clean types of the food [23]. The countries where Non-Muslim are populated, for example, China, Thailand, the Philippines and India have been at the front line of taking benefit of the worldwide Shariah compliant industry. Below table 2 illustrates the worldwide market with a high potential for halal items. These business sectors indicate another prospect for Shariah compliant food associations to frame a stage for the development in the future.

Table-1: Shariah compliant food markets with high potential

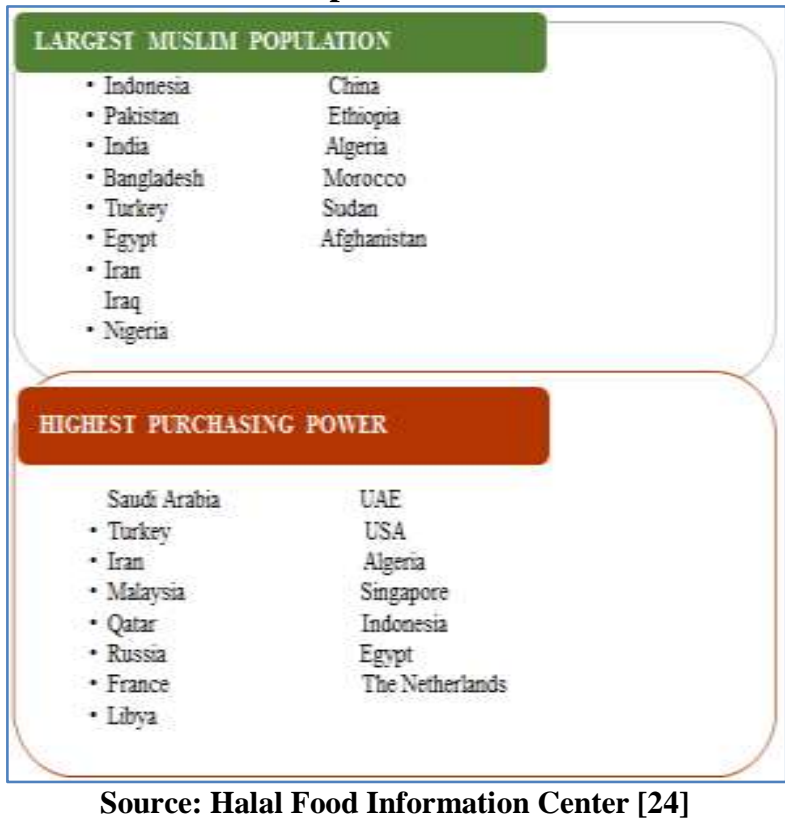

The expanded worldwide exchange has additionally provoked the interest in Shariah compliant food and possibly helped the industry transforming into the potential market. According to an information given by International Trade Center (ITC) [25], if these nine drivers are engaged the Shariah compliant food market will be changed into a vital marketplace very soon.

Firstly, consumer awareness is the key thing. Over the last ten years the first driver which is consumer awareness has already in the Shariah compliant food market has already influenced substantially on the evolution of the industry. Changes in purchaser's lifestyle crosswise over times internationally replicate variations in shopping, the 
utilization of food and eating habits. In current days, the requirement for the two things which is processed as well as fresh and hygienic food has expanded to a new market subsector of the food market (e.g., the Shariah compliant market). Besides, one more thing which is additionally another waves of life changes increasing among new generation, well coalified, knowledgeable and wealthy Muslims family, who grasp an 'Islamic contemporary with the global lifestyle'. This young group of Muslims favor a contemporary way of life and they are progressively occupied the economy of the world as a customer, producers, employees, vendors and brokers. Subsequently, these people have made a worldwide enthusiasm for typical items which comply with Shariah as well as the Islamic values.

Secondly, economics is the other key factor. Over the past decade in the economic landscape the Shariah compliant market has become a significant component. Furthermore, there has been provided an increase to the financial profile of the Shariah compliant products by the administration and business initiatives. The development of Shariah compliant businesses produces numerous financial exercises, for example, making numerous prospects for business, driving export development, innovation and research, seminars, trainings and exhibition for the business. For instance, in Thailand and Malaysia, the cooperation, identified as private Shariah compliant activities, which has significantly affected the countries' economy by advancing the improvement of SMEs as well as building up exports for the Shariah compliant food.

In terms of upgrading the food industry technology has played a huge role. Numbers of problems identified with innovative progression have had an influence on the Shariah compliant food market. The advancements of technology in production of food have driven a huge growth in processing food. Within the Sharia compliant trade, this has made an ought to progress the guidelines and certification, particularly within the range of food process, smaller scale fixings and added substances. Additional problem concerning innovation is the place where testing kits are made for utilization by the both producer and customers. These kits are needed when common manufacturing lines are constantly utilized and there is a necessity to examine for unlawful elements, for instance, piggish DNA in the items of food. By having the technological advancement and track-and-follow strategies, for example, the identification radio frequency (RFID), is widely utilized by logistic who provide the service. Though, this track-and-follow technological advancement is still in its primary phases in the halal industry.

A constant growth has been there within the awareness and acknowledgment of qualities amongst Muslim societies. The Shariah compliant business replicates the values which is shared of great food, hygiene, wellbeing, and the apprehension for creatures and the atmosphere. In the current date, the business development discloses that there's a merging of halal and standard trades in bringing genuineness, morals, an intellect of most profound sense of being within the diet and large way of life. Subsequently, this merging creates a significant catalyst to guarantee that the growth and increase of this Shariah compliant food business continues within the standard trade in the future.

Eco-ethical aspect is the next driver. The ecoethical characteristics within the Shariah compliant industry are more appropriate to the concept of 'halal and tayyib' which suggests that the thing is not only Shariah compliant but healthy, clean and harmless. For the Halal system the tayyib standards ought to be an essential portion, nonetheless eventually it assumed the very low consideration than the lawful. Likewise, sustainability as additional eco-ethical viewpoint, ought to be a characteristic portion of 'halal and tayyib' idea. For instance, some Shariah compliant foods corporations in the USA (like Saffron Road and Crescent Foods) have consolidated their 'green' components of their item plans, marketing and advertising campaigns. In future the mixture of these eco-ethical features as an idea can carry Shariah compliant foods within the typical business.

Within the current era, food safety has gotten to be a global matter, due to this the impact can similarly be felt within the Shariah compliant food business. The probabilities of revealing to food-security risks are at large for those nations who depend on the exported food. To address this issue few policies have been introduced. Encouraging the nations who involve into the export, to bring the technological advancement in use, like the high scale of water system to irrigate, hydroponics, and specially for the poultry and dairy items a farm which should be air-conditioned. The additional plan is when traders can do a coordinate investment in farming places and food industrial corporations within the country of exporter. while doing this, the risks which will arise to the food-security can be controlled. This tendency should be improved and is at large a very important key thing for the Shariah compliant food companies in the future.

With regards to political viewpoint, there have been significant variations executed by the legislature to resume Shariah compliant food items within the normal trade. As per this information, the significant variations or activities which have been executed through the administration from many of the nations within the Shariah compliant food market are the foundation of Shariah compliant guidelines, inspection and authorization process, endorsement, export promotions and many other associated activities. The administration accepts that the Shariah compliant industry cannot be underestimated, and through this type of growths can 
expose another business opening. These expansions have shown that the legislators presently esteem the scope and significance of the Shariah compliant business, and it may drive as an identifiable division of international trade.

Globally a substantial number of Shariah compliant food issues was there, like fake halal accreditation and environmental pollution of Shariah compliant food items. Hence, in many countries globally Halal is being functionalized in the regulation. The example of the country who edited the Trades Description Act in 2011 is Malaysia, expressing that the Halal logo issued by Malaysia is legitimately allowed to be utilized for the residential as well as imported Shariah compliant items, and it can be issued by certifier permitted by JAKIM [26]. This regulation and related guidelines surely demonstrate that this nation is dedicated to growing its Shariah compliant industry.

\section{Importance of CSR in the Halal Industry}

The increasing interest and awareness of Halal products and services has resulting in a rapid growth of the Halal industry worldwide including western regions such as America and Europe. Among the reasons for consuming Halal products is the religiosity factor which ensures hygiene, safety, health products and also good taste [27]. Further, the Halal certified products and services also provide assurance and trust in consumer purchasing behavior [28]. The Halal logo brings a positive brand credibility which leads to trustworthiness and also field expert [29]. Besides selecting Halal products because of their standard and quality, consumers also accept Halal products and services due to globalization which has opened the doors to integration of culture and food. This dietary acculturation is a major factor affecting customer behavior in buying Shariah items [30, 29]. In Malaysia, Halal business operators are eligible to receive tax incentives once their business is Halal certified by JAKIM (Islamic Development Department of Malaysia) [27, 31]. Therefore, Halal concept must shift beyond fulfilling the legal aspects i.e. assurance and certification of product and services; it must embrace the ethical and spiritual aspects from the beginning up to the end of the process.

As the Halal industry stems from Islamic law and regulations, it should also encompass every aspect of business that should not only emphasis on profit making but with providing sustainable benefits to society. Previous researches have shown that business sustainability could be achieved through the realization of CSR which has developed beyond providing for social needs [32]. In fact, CSR has evolved toward benefits for both the receiver and creating additional value to the firms' performance [33].
Even though the CSR concept has been discussed in terms of its similarity with giving back (sadaqah) and its vital application in the industry standard, surprisingly even with the specialist literature on CSR in the Halal industry, these researches are yet to provide a significant impact to the knowledge. Specifically, not many studies have emphasized CSR in the Halal industry [34], and the only eminent example of CSR research related to Halal is in banking and finance e.g. Amran [35], Hashim [36]. Current situation does not deliver a conclusive understanding of CSR in the Halal industry in a bigger context. According to Zam [37] CSR awareness and disclosure in the Halal industry is relatively low. Thus, CSR is important to be introduced to create shared values in fulfilling a holistic Halal ecosystem agenda. Through CSR, Halal business will promote an ethical environment in line with the aspiration of Islamic moral economy by focusing on these axioms: tawhīd (God consciousness), 'adl (justice), amānah (honesty) and akhlāq [38] in a normative sense and financial principles in a positive sense [39]. Islamic moral economy is represented as a perfect economic system, which focuses for an ideal economic order in the sense of first best result based on Shariah advocating socio-economic fairness with individuals directing at falāh by maximizing ihsan (beneficence).

\section{Halal Corporate Information}

In the year 2011, the food industrial market in Malaysia encompass of nearly three thousand two hundred producers that subsidized approximately 10 percent of the nation's industrial production [40]. In spite of that, the country is still required to bring food products from different Nations like Australia, New Zealand, and USA. All these importations are continuously rising in standard of 23 percent from the previous years. There is no doubt, food products are requirements for humanity. For the country like Malaysia in which the greater part of its people is from Muslim community, taking Shariah compliant food and other food items are not a choice however it is a compulsory for a person who is Muslim. Therefore, Shariah compliant market in this country has increased remarkably because of the growing supply for the Shariah compliant food items and other services from domestic and the global trade. And halal accreditation and guideline were then established to support consumers from Muslim community to identify any of the item which had fulfilled the Islamic values in the manufacturing procedures as Shariah compliant [41]. Regrettably, many industries are there which unfairly and carelessly faking the halal accreditation as well as its logo established by Malaysian Islamic Development Department (JAKIM) with the purpose to control Muslim marketplace as well as make high revenue. 


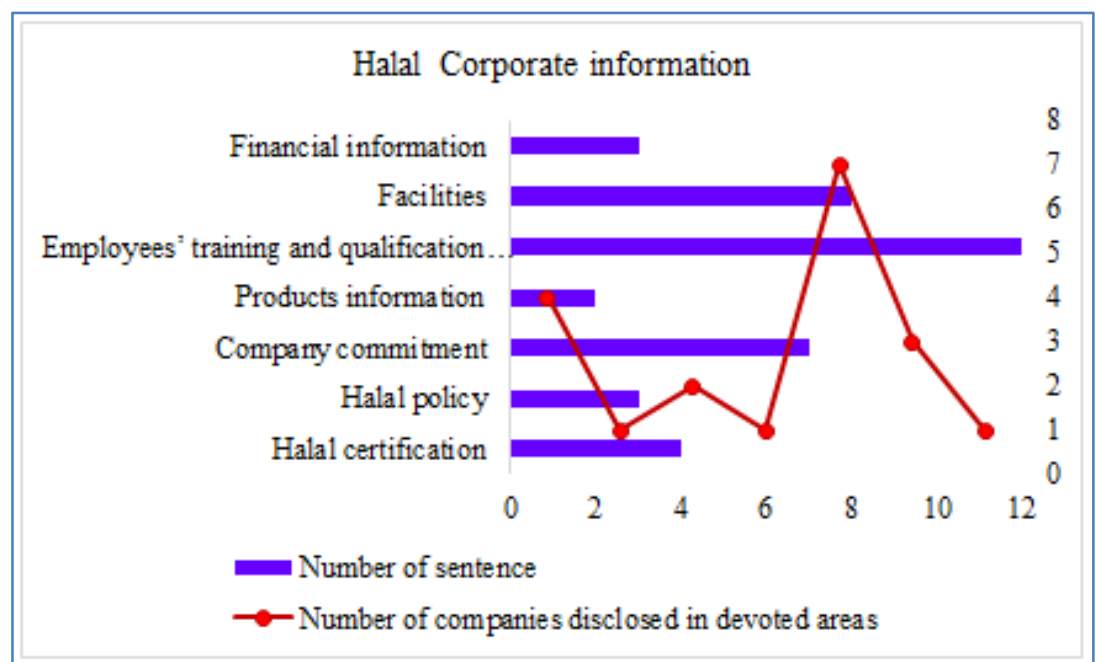

Fig-5: Halal corporate information; Adapted from: Halal Related Information: Corporate Social Responsibility Disclosures by Malaysian Food Industries [42].

According to Wan and Razak [42], 4 organizations stated that the halal accreditations acquired. However, there are 7 organizations who gave short history as well as education requirement of their Shariah compliant committee or advisory board. As the certifications were provided through JAKIM or some of the trained third organizations so provision of such information would increase consumers' confidence. Another 2 organizations stated their firms' assurance to follow to Shariah compliant values by abiding the regulations as well as process build up by Shariah. Nevertheless, there is only one firm informed that major actions two of its diversions are "producing and sales of frozen Shariah compliant food items". Around three firms revealed that they invested money either in Shariah compliant services, or their plants are situated in Halal-Hub. In the meantime, financial associated information encompasses of revelation related to Shariah compliant Hub tax incentive approved to the firms. Only one company is there who attempted to bring Halal Policy and dedicated a separate section to unveil regarding Shariah compliant data. Its Halal Policy is elaborated as below:

"It is necessary for the company $\mathrm{X}$ always to follow to the Malaysian Halal Standards MS1500:2009 in guaranteeing that items manufactured are Shariah compliant, hygienic and harmless to use it. The honesty of the procedure begins from obtaining of raw ingredients to producing, storing, packaging and depositing of the items. It is also the responsibility for the company $\mathrm{X}$ to ensure that items produced for the group either made domestically or brought from cross border complies with Halal benchmarks of the nation of origin, or which is additionally perceived by JAKIM".

Despite the fact that Halal is not a problem that is taken casually by corporations, giving information associated to Halal should be deliberated as similarly significant to allow customers to be well-informed with Halal problems and matters which are apprehended by the corporations. Shareholders as well as the stakeholders should show dynamic part to guarantee the corporations reveal information associated to Halal, so they can be considered responsible and liable for their activities and decisions.

\section{Halal CSR Content}

There are various studies compassed on the disclosures of CSR to inspect the degree of revelations, and the superiority of disclosures related to CSR in the annually published data which is directing on participation of the society as well as atmosphere. Though, studies on disclosures of reports related to Halal through corporations as the part of disclosures related to CSR are still deficient. To ensure that industries are responsible for their activities as well as performances, industries are predicted to provide account of its activity to other parties [43]. Whereby, in its activities and operations they will need to be more transparent. The shareholders and further stakeholders such as costumers, creditors, and workers reserve the privilege to recognize not only about halal certified items but also the entire procedures starting from 'farm to table'. This idea is identified as permitted and clean which combined of Halal as well as Toyyiban. On these issues' disclosures may assist as a declaration to the shareholders and further stakeholders to guarantee they have selected goods which are really achieve the guidelines build up by JAKIM.

However, despite the fact that the halal CSR data can be measured to be unimportant by the corporations due to the lower degree of disclosure, over 60 percent of them spoken the significance of halal guidelines in their processes. It was exposed when 21 percent revealed in the statement of chairman and further 21percent comprised in as portion of the CSR disclosure. Disclosure in Financial Report (16\%), Individual Section and Business Review (5.2\% each) demonstrated its addition with the mainstreams matters of the corporation. 
The degree of disclosure by corporations that gave Halal CSR data is comparatively little as associated to other CSR disclosure like society, atmosphere or employees. However, disclosure parts dedicated the halal CSR data demonstrate that Halal matters are genuinely measured by the organizations and had been demonstrated as part of the trading processes. On the other side, the material of disclosure directed on gaining assurance for costumers where the firms' pressure on the authorization and endorsement accomplished from others.

\section{CSR -Halal Consumers' Perspective}

Through CSR, consumers expect a good standard of quality for all Halal products and services [38] as it needs to comply with the basics of Maqașid Shariah (objective of Shariah) - the public good. Consumers would not need to worry about product defect, poor service or any unethical dealings as Islam always promotes justice for both buyer and seller. Consumers are very particular with the substance, which is about safety, truthful information, good quality and also respecting individuals' rights.

This section describes the familiarity of Halal consumers on the concept of CSR. The objective is to gauge the knowledge and awareness of CSR especially in the Halal industry. From the survey, the majority of respondents $(70.1 \%)$ reported familiarity with CSR concepts while $8.4 \%$ reported otherwise. Only $21.4 \%$ of the respondents are unsure about CSR. This implies a good knowledge of CSR from the society. Thus, Malaysians are considered to be aware of being socially responsible toward the society and environment.

In the conducted survey respondents were questioned on the meaning of CSR according to the list given: (i) giving back to community, (ii) donation and/or philanthropy, (iii) people, planet and profit, (iv) business and community, (v) business integrity, (vi) corporate sustainability and (vii) responsible business. According to the respondents' knowledge, $45.8 \%$ of the respondents defined CSR as giving back to society, while $17.1 \%$ understood that CSR means business and society. Moreover, $15.1 \%$ of the respondents associated CSR with charity and/or philanthropy. According to Shamir [44] and Graafland [45], CSR is usually viewed as a philanthropic act or conserving the environment. In addition, Siwar [46] and Graafland [45] also associate CSR with charitable activities. Then, $10.1 \%$ respondents defined CSR as responsible business and $4.3 \%$ of respondents related CSR to the concept of business ethics. Finally, respondents described CSR as people, planet and profit; and corporate sustainability, with each definition representing $3.8 \%$ of respondents. Thus, it can be concluded that there is relatively high awareness and good comprehension of CSR among the Halal consumers since their perceptions are beyond the dogma of philanthropy and charity.

\section{Exploration of CSR in Halal Industry}

Halal literacy influences the process of knowledge, persuasion, decision making and conformation in business transactions [47]. In understanding the overarching concept of Halal business, it encompasses a wider perspective rather than maximizing profit and receiving legal recognition on Halal i.e. Halal certification and Halal assurance. Halal business must also ensure ethical and integrity in order to be considered as Halal business as it is important to ensure the welfare of all stakeholders involved. Therefore, we need to do promotion and enhance Corporate Social Responsibility (CSR) in order to achieve Halal business sustainability and also to achieve the holistic view of Halal.

According to the results of a survey, the respondents ranked 'help local communities' among the most anticipated CSR activities to be practiced in Halal industries with a mean score of 4.391. This aligns with the study of Laudal [48] which identified that CSR is often offered to local communities especially for Small Medium Enterprise (SMEs). Then, safety became the second major concern for CSR activities with a mean score of 4.383. The consumers of Halal industries also demanded the Halal business sector to 'provide truthful information' (4.380). Transparency is an important element in order to gain consumer trust [49], and [42]. Respondents also want Halal business to 'offer quality products and services' with a mean score of 4.380 and respect individuals' rights with a mean score of 4.354 . 'Investing in ethical and Shariah compliant products' comes in sixth place $($ mean $=4.333$ ) which suggests that respondents perceived substance beyond form. The rest of the CSR activities, except for 'business needs to focus on maximizing profit' (mean score 2.957), generates good responses on the agreeableness of the activities. The results show that the understanding of CSR on giving back to society has been proven to be the highest selection of CSR activities in helping local communities. Then comes the concern for safety, truthful information and quality of Halal products and services according to a standard quality acceptable worldwide [38]. Interestingly, these Halal consumers have ranked sixth for ethical and Shariah investment and ranked eleventh for assisting Zakāh house implying that these religious activities are less important compared to giving back to community and the substance of the products and services.

\section{Motivation of CSR for Halal Industry}

This section provides results on consumers' inspiration for involving in CSR movements conducted for the Halal industry. The question which was asked to consumers is "what is the motivation for Halal consumers to engage in CSR activities?" [15]. 


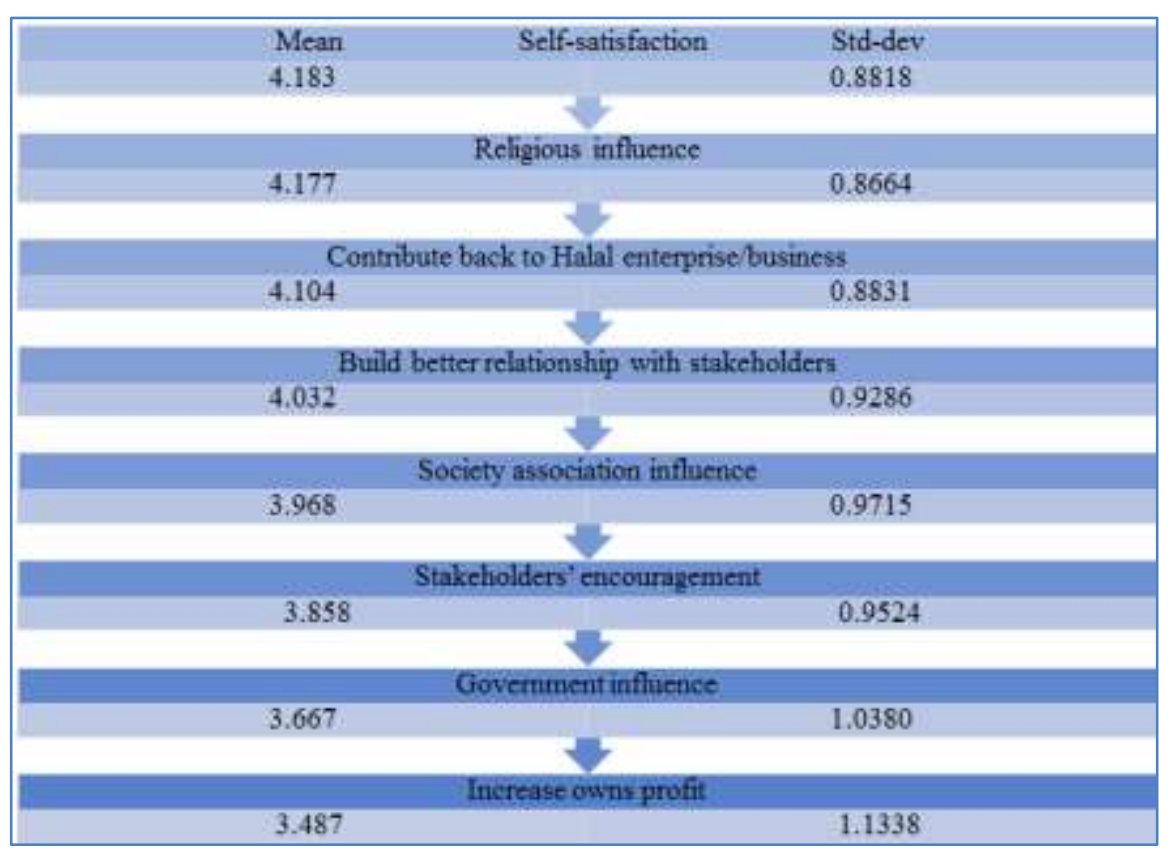

Fig-6: Motivation for CSR is arranged according to the highest to lowest mean rank. Adapted from: [15]

The aim of this question is to inspect the willingness of Halal consumers in engaging in CSR activities. The assessment was employed using a 5point Likert scale of 1 (strongly disagree) to 5 (strongly agree) (refer Table 4). Reliability analysis of the eight items yielded a Cronbach's alpha of 0.901 indicating a strong reliability to further test the items [50].

The results in Table 3 reveals that the main motivation for Halal consumers to engage in CSR is because of 'self-satisfaction' (mean $=4.183$ ), 'religious influence' (mean $=4.177)$, 'contribute back to the business' (mean $=4.104)$ and 'build better relationship with stakeholders' (mean = 4.032). However, respondents were indecisive whether to agree or disagree on the rest of the items with mean scores ranging from 3.487 to 3.968 . Respondents least favor 'increase own profit' (mean $=3.487$ ) and also 'governmental influence' (mean $=3.667)$ as it is ranked the lowest. These results are against the idea of Friedman (1970) on maximizing profit and claiming that social welfare is the government's responsibility.

Therefore, it can be concluded that the motivation for Halal consumers engaging in CSR activities is purely voluntarily because of selfsatisfaction and contributing back to the company. Nonetheless, religious influence is the key driver for consumers to contribute to CSR activities [51] which also coincides with Shah Alam and Mohamed Sayuti [30]. It shows that religion of Islam has huge impact in business decision as a manifestation of being accountable and obedience to [52] besides fulfilling business strategy in realizing the economic responsibility [53].
On the other hand, this research has integration of religiosity and being socially responsible which is value added for CSR literature especially on Islamic CSR. According to the neither study of Nor, Shifa Mohd [15] apart from self-satisfaction, religion has significant impact in motivating consumers and also Halal business to perform a strategic iCSR activity. Islamic CSR imposes the fulfilment of Islamic morality on the Halal ecosystem which indicates that every activity in the Halal industry must be according to substantive morality informed by higher objectives of Islam - maqașid Shariah. Thus, the Halal industry will enjoy economic and instrumental benefits (i.e. profit, good brand image, business sustainability etc.) [14] and spiritual rewards (blessings from Allah). A holistic Halal ecosystem can be achieved through the spirit of Islamic CSR.

\section{CONCLUSION}

The current work attempts to explore CSR practice in the Halal industry which was neglected. In the Halal industry the consumers are aware and understand the underlying concepts of CSR including giving back to society and also highlighting ethical issues in business such as transparency and good governance. Thus, CSR activity is beyond philanthropy and charitable activities. For the Halal products consumer, the acceptance of CSR is not only on moral issues but also creating value for the business. Therefore, embracing the CSR in Halal industry would lead to business sustainability. It is suggested that future scholars utilize a subjective approach to gauge healthy data on the motives for performing CSR and the significance of CSR in guaranteeing sustainability of the Halal business. 


\section{REFERENCES}

1. Yaakob CM. Updates on global halal research \& development, World Halal Research 2009 Summit, 7 - 8 May, 2009, Halal Industry. Development Corporation, KLCC Kuala Lumpur, Malaysia. Halal Products Research Institute, Universiti Putra Malaysia, 2009.

2. Wong $\mathrm{Li} \mathrm{Za}$. Malaysia: Halal benchmark, 5th World Halal Forum [Internet]. 2010 [cited 2020 March 13] Available from: http://halalfocus.net/2010/06/28/malaysiahalalbenchmark/, 2010.

3. The global halal industry: an overview [Internet]. 2013 [cited 2020 March 13] Available from: http://www.gifr.net/gifr2013/ch_13.PDF

4. Riaz MN, Chaudry MM. Halal food production. CRC. 2003 Oct 28.

5. Davis K. The case for and against business assumption of social responsibilities. Academy of Management journal. 1973 Jun 1;16(2):312-22.

6. Carroll AB. Academy of Management Review. A three-dimensional conceptual model of corporate performance. 1979;4(4):497-505.

7. Suhana M, Mohammad N, Suhaiza Z, Mohd A. Islamic values and corporate social responsibility in a food supply chain. Australian Journal of Basic and Applied Sciences. 2014;8(1):513-20.

8. Watts P. Corporate social responsibility: making good business sense. World Business Council for Sustainable Development; 2000.

9. Carroll A. Corporate social responsibility in Visser W, Matten D, Pohl M and Tolhurst, N. (Eds), The A to $\mathrm{Z}$ of Corporate Social Responsibility, ICCA Publication, John Wiley \& Sons, Chichester, 2007: 122-31.

10. Carroll AB. Corporate social responsibility: Evolution of a definitional construct. Business \& society. 1999 Sep;38(3):268-95.

11. Simon FL. Global corporate philanthropy: a strategic framework. International Marketing Review. 1995 Aug 1.

12. European Commission. Corporate Social Responsibility [Internet]. 2010 [cited 2020 March $\left.2^{\text {nd }}\right]$. Available from: http://ec.europa.eu/enterprise/policies/sustainableb usiness/corporate-soci responsibility/index_en.htm

13. McWilliams A, Siegel D. Corporate social responsibility: A theory of the firm perspective. Academy of management review. 2001 Jan 1;26(1):117-27.

14. Carroll AB. The pyramid of corporate social responsibility: Toward the moral management of organizational stakeholders. Business horizons. 1991 Jul 1;34(4):39-48.

15. Nor SM, Ali MH, Abdul-Rahman A, Subakir NN. Exploring CSR in Halal Industry: Insights from Malaysia. International Journal of Economics, Management and Accounting. 2019 Dec $31 ; 27(2): 423-43$.
16. Dusuki AW, Abdullah NI. Maqasid al-Shariah, Maslahah, and corporate social responsibility. American Journal of Islamic Social Sciences. 2007 Jan 1;24(1):25.

17. Muhamad R. Corporate social responsibility: An Islamic perspective. International Conference on Global Research in Business and Economics Bangkok, Thailand; 2007.

18. Thomson Reuters. State of the Global Islamic Economy Report 2017/18 [Internet]. 2017. Available from: https://doi.org/10.1017/CBO9781107415324.004

19. Shaw WH. Marxism, business ethics, and corporate social responsibility. Journal of Business Ethics. 2009 Feb 1;84(4):565-76.

20. Muslim ibn al-Hajjāj. Șaḥịh Muslim. Riyadh: Dār al-Salām; 2000.

21. Global Islamic Finance Report, Overview of the Global Islamic Finance Industry [Internet]. 2017 [cited 2020 March 11]. Available from: http://www.gifr.net/publications/gifr2017/intro.pdf

22. Pew Research Center. The Future of World Religions: Population Growth Projections 20102050 [Internet] 2015. Available from: <http://www.pewforum.org/2015/04/02/religiousprojections-2010-2050/>.

23. Zulfakar MH, Anuar MM, Ab Talib MS. Conceptual framework on halal food supply chain integrity enhancement. Procedia-Social and Behavioral Sciences. 2014 Mar 19; 121:58-67.

24. Halal Food Information Center. Thailand [Internet]. 2016 [cited 2020 February 17]. Available from: http://www.thaihalalfoods.com/EN/industry.php?id $=17>$.

25. ITC. From Niche to Mainstream - Halal Goes Global, International Trade Centre [Internet]. 2015 Available from: http://www.intracen.org

26. Zakaria Z. Tapping into the world halal market: some discussions on Malaysian laws and standards. Jurnal Syariah. 2008 Sep 1;16(3):603-16.

27. Ambali AR, Bakar AN. People's awareness on halal foods and products: Potential issues for policy-makers. Procedia-Social and Behavioral Sciences. 2014 Sep;121(19):3-25.

28. Ali A, Ali A, Xiaoling G, Sherwani M, Hussain S. Expanding the theory of planned behaviour to predict Chinese Muslims halal meat purchase intention. British Food Journal. 2018 Jan 2.

29. Wibowo MW, Ahmad FS. Non-Muslim consumers' halal food product acceptance model. Procedia Economics and Finance. 2016 Jan 1;37(16):276-83.

30. Alam SS, Sayuti NM. Applying the Theory of Planned Behavior (TPB) in halal food purchasing. International journal of Commerce and Management. 2011 Mar 15.

31. Wan NZ, Saidi N, Razak S. Halal related information: Corporate social responsibility disclosures by Malaysian food industries. Journal of Applied Environmental and Biological Sciences. 
2014 Jan:35-9.

32. Marques-Mendes A, Santos MJ. Strategic CSR: an integrative model for analysis. Social Responsibility Journal. 2016 Jun 6.

33. Nazri MA, Omar NA, Hashim AJ. Corporate social responsibility and market orientation: An integrated approach towards organizational performance. Jurnal Pengurusan (UKM Journal of Management). 2018 Jul 1;52.

34. Asutay M, Azid T. Does ethico-moral coalition complement to economic coalition? a response in the periphery of Islamic economics. Humanomics. 2007;27(3):153-73.

35. Amran A, Fauzi H, Purwanto Y, Darus F, Yusoff H, Zain MM, Naim DM, Nejati M. Social responsibility disclosure in Islamic banks: a comparative study of Indonesia and Malaysia. Journal of Financial Reporting and Accounting. 2017 Apr 10.

36. Nor SM, Hashim NA. CSR and sustainability of Islamic banking: The bankers view. Jurnal Pengurusan (UKM Journal of Management). 2015;45.

37. Wan NZ, Saidi N, Razak S. Halal related information: Corporate social responsibility disclosures by Malaysian food industries. Journal of Applied Environmental and Biological Sciences. 2014 Jan:35-9.

38. Ibrahim O, Samsi SZ, Ahmad MF. Halal Business Corporate Social Responsibility. InInternational University Social Responsibility Conference and Exhibition 2010 (IUSRCE 2010 \& 2nd USRIC 2010), PWTC, Kuala Lumpur 2010.

39. Tripp C. Islam and the moral economy: The challenge of capitalism. Cambridge University Press; 2006 Jul 20.

40. Food Export Midwest. Malaysia country profile [Internet]. 2014 [cited 2020 March 13]. Available from:

http://www.foodexport.org/Resources/CountryProfi leDetail.cfm?ItemNumber+1029

41. El Garah W, Beekun RI, Habisch A, Lenssen G, Adaui CL, Ismaeel M, Blaim K. Toward applied Islamic business ethics: responsible halal business.
Journal of Management Development. 2012 Oct 19.

42. Wan NZ, Saidi N, Razak S. Halal related information: Corporate social responsibility disclosures by Malaysian food industries. Journal of Applied Environmental and Biological Sciences. 2014 Jan:35-9.

43. Williams PF. The legitimate concern with fairness. Accounting, organizations and society. 1987 Jan 1;12(2):169-89.

44. Shamir R. The de-radicalization of corporate social responsibility. Critical Sociology. 2004 May;30(3):669-89.

45. Graafland J, Mazereeuw C, Yahia A. Islam and socially responsible business conduct: an empirical study of Dutch entrepreneurs. Business Ethics: A European Review. 2006 Oct;15(4):390-406.

46. Siwar C, Harizan SH. A study on corporate social responsibility practices amongst business organizations in Malaysia. Bangi: Institute for Environment and Development, Universiti Kebangsaan Malaysia. 2009 Apr.

47. Antara PM, Musa R, Hassan F. Bridging Islamic financial literacy and halal literacy: the way forward in halal ecosystem. Procedia Economics and Finance. 2016 Jan 1;37:196-202.

48. Laudal T. Drivers and barriers of CSR and the size and internationalization of firms. Social Responsibility Journal. 2011 Jun 7.

49. Amacanin MC. The Strategic implications of corporate responsibility and sustainability in the $u k$ banking sector (Doctoral dissertation, University of Nottingham).

50. Bryman A. Social research methods. Oxford university press; 2016.

51. Brammer S, Williams G, Zinkin J. Religion and attitudes to corporate social responsibility in a large cross-country sample. Journal of business ethics. 2007 Mar 1;71(3):229-43.

52. Murphy MJ, Smolarski JM. Religion and CSR: An Islamic "Political" Model of Corporate Governance. Business \& Society. 2018;59(5):82354.

53. Sharp Z, Zaidman N. Strategization of CSR. Journal of business ethics. 2010 Apr 1;93(1):51-71. 